\title{
A Clinical Study to Evaluate Efficacy of Agnikarma (Locally) and Ashwagandha Ghanavati (Internally) in the Management of Manyagata Vata w.s.r Cervical Spondylosis
}

\author{
Research Article
}

\author{
Dwivedi Amarprakash $^{1}$, Pathrikar Anaya ${ }^{2}$, Kamble Shubhangi $^{3 *}$, Kulkarni Anjna $^{4}$ \\ 1. Professor, 3. PG Scholar, 4. PhD Scholar, \\ School of Ayurveda, D Y Patil University, Navi Mumbai, India \\ 2. Ph.D.(Scholar), Tilak Maharashtra Vidyapeeth, Pune, India
}

\begin{abstract}
Cervical Spondylosis is described as degenerative condition of the cervical spine. It is found most commonly in individuals aged 40-60 years, leads to symptoms like pain, restricted movement stiffness and tingling-numbness at neck region. In Ayurveda, it can be correlated with Manyagata Vata which is managed with various Panchkarma such as Basti, Raktamokshan ,Nasya, Agnikarma etc. Adjuvant to Vata-Kaphashamak and Asthi Dhatuvardhan palliative drugs. The Agnikarma though effective tool for pain management has varied results due to fluctuation in temperature from intermittent heating of shalaka (metallic probe).To overcome this, conventional Agnikarma device is modified with temperature controlling unit (produces constant temperature) and Raupya Shalaka (specially designed silver probe having micro rods)which helped in minimizing the pain as heat is delivered once at desire site. Adjuvantly, A shwagandha Ghanavati (internally) was given, which acts as Rasayan to Asthi Dhatu (rejuvenating bone tissue). The combination treatment showed statistically significant results in relieving symptoms such as pain, stiffness, flexion, extension, lateral movement of neck and tingling numbness. Out of 50 patients, $92 \%$ patients got complete relief from cervical pain, $98 \%$ patients got relieved from Stiffness whereas restricted movements of neck and tingling numbness present was relieved in $96 \%$ patients. The device helps in keeping the temperature constant $\left(60^{\circ} \mathrm{C}\right)$ throughout the procedure \& desired heat is delivered by keeping the probe in contact for 10 seconds at affected site. In this study,Agnikarma with modified device and AshwagandhaGhanavatirevealed their efficacy in relieving symptoms of Manyagatavata. Further, the Agnikarm with modified deviceproved user friendly, safe (without iatrogenic effects) and made procedure swift.
\end{abstract}

Keywords: Cervical spondylosis,Manyagatavata, Agnikarma, Ashwagandha Ghanavati.

\section{Introduction}

Cervical Spondylosis is described as degenerative condition of the cervical spine. Pathology starts at the intervertebral discs and dehydration of discs results in reduction of intervertebral discspace and peripheral osteophytes formation. It is found most commonly in individuals aged $40-60$ years. It leads to neck pain, stiffness in the cervical joints, etc. In allopath treatment, palliative medicines requires long term, frequent administration and have untoward effects, hence, there use is limited. Further, in advancement of disease (CSM and Neurological involvement) surgical intervention like laminectomy, decompression, implants etc. are practiced with due risk(1). This gives scope to Ayurveda which has several treatments alternatives for vitiated Vayu in Manyapradesh (neck region).

The description about Manyagata Vata is not available as a separate disease but, mentioned as one of

\section{*Corresponding Author:}

\section{Kamble Shubhangi}

PG Scholar,

School of Ayurveda,

D Y Patil University, Navi Mumbai, India

Email:drshubhikamble@gmail.com the Vatavyadhi in Charak Samhita As per clinical manifestation, it can be co-related to cervical spondylosis. Ayurveda offers treatment like Panchkarma modalities such as Snehana (oleation), Swedana (fomentation), Basti (Medicated enema), Sthanik Lepa (local paste application), Nasya (intra nasal drug therapy)etc. adjuvant to Vata-Kaphashamak and Dhatuvardhan(nourishing tissue)palliative herbal $\operatorname{drugs}(2)$.

Similarly, Agnikarma (intentional heat burn therapy) is also practiced treating Asthigat-Vata induced by vitiated Vata with instant pain management (3).Though, it has been practiced since thousand years, this ancient method of Agnikarma consist of limitations like dependency to poor heat source(flame), intermittent heating of shalaka (heat delivering probe) and fluctuation of temperature and due risk of iatrogenic burns. Hence, to overcome these limitations, conventional Agnikarma device is modified with temperature controlling unit and Raupya Shalaka (specially designed silver probe having micro rods ) which helps in minimizing the pain (as heat is delivered once at desire site). This device helps in keeping the temperature constant $\left(60^{\circ} \mathrm{C}\right)$ throughout the procedure and require single sitting. To deliver the desired heat burn, device is switched on and the probe is kept in contact for 10 seconds at affected site. The specially designed kurchak (brush) type of RaupyaShalaka 
(silverprobe having micro rods) produces Grade 2 burn (Bindu/dot type of Agnikarma) at desire site (4). It produces Samyak-Dagdhavrana rahit Agnikarma (adequate heat burns without scar) and also minimizes risk of iatrogenic burn.

The adjuvant palliative drug Ashwagandhapossess properties such asTikta Rasa(bitter taste),Rasayan (rejuvenator) and Balya(nourishing) which helps in controlling degenerative changes and also consist of Cox -2 enzyme which helps in relieving pain and break the pathogenesis(5).

Hence, the proposed study was primarily aimed to evaluate the efficacy of Agnikarma and Ashwagandhaghanavati in Manyagatavataw.s.r. to cervical spondylosis.

\section{Methodology \\ Study Design}

Type of study - Open (Non Blind), Uncontrolled (Single Arm), Clinical study.

Place of Study - Shalya Department of D.Y.Patil Ayurvedic Hospital, Navi Mumbai.

Sample Size - 50 patients

\section{Material/ Drug}

1. Modified Agnikarma device (temperature controlling unit) with specially designed probe RoupyaShalaka (kurchak(brush) type of specially designed silver probe having micro rods)

2. Ashwagandha Ghanavati (Withania somnifera) internally.

\section{Dosage \& Time}

- Agnikarma- 2 sittings of Agnikarma keeping the temperature constant $\left(60^{\circ} \mathrm{C}\right)$ throughout the procedure was given at the interval of 15 days, and probe (shalaka) is kept in contact with skin for duration of 10 seconds at most painful site.

- AshwagandhaGhanavati-2 Tablets (of 250mg each) was given twice a day with warm water for 60 days after meals adjuvent to A gnikarma therapy.

\section{Duration (follow up)}

Patient was observed for 90 days . However, 2 sittings of Agnikarma at the interval of 15days and adjuvant palliative medicine was given for 60 days only. Simultaneously, the follow up prognosis was recorded in the CRF to draw conclusion.

\section{Criteria for Inclusion}

Patients between age group 30 to 60 , having clinical features such as pain in cervical region, stiffness, restricted movements of neck and, tingling numbness in upper extremities, irrespective of gender, and X- Ray showing early degenerative changeswere included in the study.

\section{Criteria for Exclusion}

Patients with Pott's Spine, Ankylosing spondylosis, Kyphosis, Peripheral neuropathies, Metastatic disease of spine, Rheumatoid arthritis, Traumatic Inter vertebral disc prolapsed, diabetic neuropathy with radiculopathy, Multiple sclerosis's disease, Coagulative disorders were excluded.

\section{Modified Device of Agnikarma \\ Temperature controlling unit(6)}

The temperature controller takes an input from a temperature sensor and has an output that is connected to a control element. It compares the actual temperature to the desired control temperature, or set point, and provides an output to a control element

This electronic device consists of (i). Electronic Device (ii). The handle which consists of coil (which helps in heating) and specially designed probe (kurchak type specially designed silver probe having multiple small micro rods).

Modified Probe (kurchak type silver probe having multiple small micro rods)

The specially design Raupya shalaka resembling shape of Trikurchak shashtra (brush) mentioned in Sushrut Samhita had been used for Agnikarma in this study.

Kurchak (brush) type of Raupya shalaka consists of multiple small micro rods of sliver which produces the grade 2 burn at once, instead of multiple burns on different affected site.

This probe has been designed to minimize the pain by applying it on skin for once for mere 10 seconds, utmost tender(painful)part, thus, making the procedure user friendly, safe (without iatrogenic effects) and making procedure swift.

Image 1: Modified Agnikarma Device (Temperature controlling unit with probe)

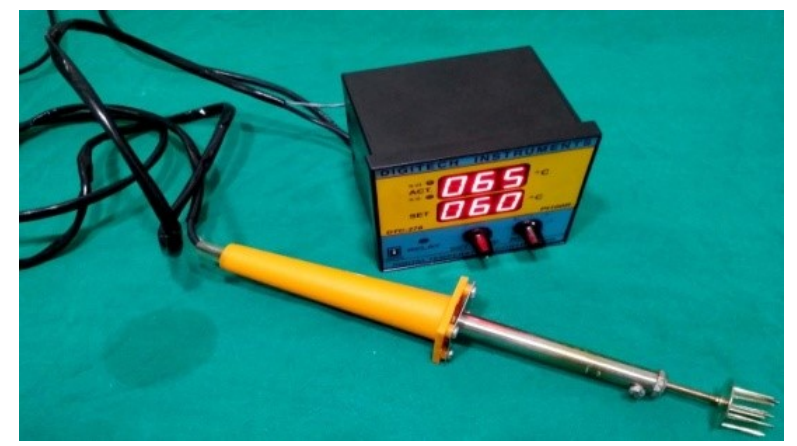

AshwagandhaGhanavati (Withaniasomnifera) Ashwagandhahas properties like Rasayana, Balya, Vatasamak,Shothhara(anti-inflammatory properties) which are helpful in controlling degenerative changes(7). Ashwagandhaalso possess analgesic effect as it consists of cox-2 enzyme that acts on the nervous system to prevent pain signals from being sent.

\section{Method of preparation \\ Collection-}

Ashwagandha bharad (crude form) had been purchased from APMC market, Navi Mumbai.

\section{Authentication \& Standardization}

Drug authentication was done at Mithibai College (botany laboratory) Mumbai and Standardization was done in Alarsin Pharmacy. 


\section{Preparation}

Ashwagandha bharad of $5 \mathrm{~kg}$ added with 16 times of water and is boiled till the whole contents are reduced to $1 / 4^{\text {th }}$. On cooling it was strained into another vessel.The filtered liquid is placed in a broad based vessel and heated over simmer to moderate flame.Heating was continued till all the moisture was evaporated and only powdered sediment was left alone.Then it was taken out from the fire and preserved in air- tight container.Ashwagandha Ghana had been prepared of about $1 \mathrm{~kg}$.After this the vati(tablets) weremade by rolling in round mass which is Ashwagandha Ghanavati.(8)

It was dried for 2 days after which the standardization test has been done. After standardization test Ashwagandha ghanavati is used on patient.

\section{AGNIKARMA PROCEDURE (9)}

Purvakarma(Pre-procedure):

Patient was made aware of the procedure by explaining them and written/ inform consent was taken from the patient prior treatment. After taking the consent patient is allowed to sit comfortably and the most tender point at cervical region was marked with the marker. Prior starting treatment the Modified Agnikarma device (temperature controlling unit with probe) checked for electric connection and kept ready. Then the desired site where Agnikarma is to be done was properly cleaned with distilled water allowed to dry.

\section{Pradhankarma(Main procedure):}

After cleaning the site, the temperature is set on 60 degree Celsius, and then with the help of probe (kurchak type of raupyashalaka)the Agnikarmais performed on most tender site as marked and bindu(dot) type of grade 2 heat burn is delivered, till it produces Samyak-Dagdhavrana rahit Agnikarma (adequate heat burns without scar) The shalaka is kept in contact of skin for duration of 10 seconds. This is done only once as the shalaka consist of multiple micro rods to obtain desired effect of A gnikarm.

Image 2:Agnikarmademonstration with Modified Agnikarma Device

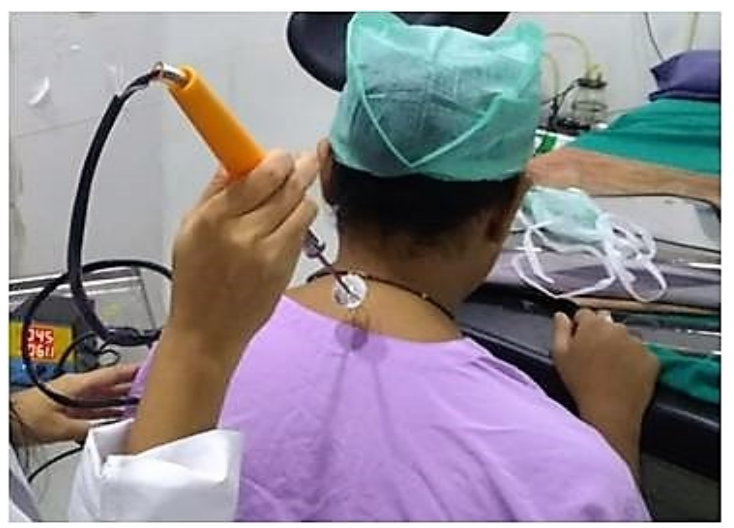

\section{Paschat karma (Post procedure):}

After the adequate Agnikarma procedure, Yastimadhughrit (medicated clarified butter) was applied at the site of Agnikarma for relieving post burn pain and discomfort. This also promotes healing of post burn wound. As the probe is kept in contact with skin only for $10 \mathrm{sec}$ (at 60 degree Celsius) post burn scar do not occur. Hence, this procedure can be named as Daghdavrana rahit Agnikarma.

\section{ASSESMENT CRITERIA (10)}

Table 1: showing the gradation of parameters for the study

\begin{tabular}{|c|c|c|c|c|}
\hline Parameters & \multicolumn{4}{|c|}{ Gradation } \\
\hline \multirow[t]{2}{*}{ Pain } & $\mathbf{0}$ & $1-3$ & 4-7 & 8-10 \\
\hline & No pain & Mild pain & Moderate pain & Severe pain \\
\hline & $\mathbf{0}$ & 1 & 2 & 3 \\
\hline Stiffness & No stiffness & $\begin{array}{l}\text { Mild Stiffness no } \\
\text { medication required }\end{array}$ & $\begin{array}{l}\text { Stiffness, relived by } \\
\text { external application }\end{array}$ & $\begin{array}{l}\text { Stiffness, is not } \\
\text { responded by } \\
\text { medicine }\end{array}$ \\
\hline Flexion & $\begin{array}{l}\text { No restriction- Able to } \\
\text { touch the inter } \\
\text { clavicular line }\end{array}$ & $\begin{array}{l}\text { Upto } 2 \mathrm{~cm} \text { difference } \\
\text { between the chin and } \\
\text { interclavicular line - }\end{array}$ & $\begin{array}{l}2-4 \mathrm{~cm} \text { difference } \\
\text { between the chin and } \\
\text { inter clavicular line }\end{array}$ & $\begin{array}{l}\text { More than } 4 \mathrm{~cm} \\
\text { difference }\end{array}$ \\
\hline Extension & $\begin{array}{l}\text { Normal i.e. able to } \\
\text { extend the head up to } \\
\text { the level when nose tip } \\
\text { and forehead becomes } \\
\text { in horizontal plane } \\
\text { approximately flexion to } \\
\text { extension } 130 \text { degree }\end{array}$ & $\begin{array}{c}\text { Moving up to } 120 \\
\text { degree }\end{array}$ & $\begin{array}{l}\text { Movement up to } \\
110-120 \text { degree }\end{array}$ & $\begin{array}{c}\text { Movement }<120--- \\
\text { degree }\end{array}$ \\
\hline $\begin{array}{l}\text { Lateral } \\
\text { movement }\end{array}$ & $\begin{array}{c}\text { Normal i.e. able to make } \\
\text { complete rotation of } \\
\text { neck }\end{array}$ & $\begin{array}{l}\text { Rotation with little } \\
\text { difficulty }\end{array}$ & $\begin{array}{l}\text { Rotation side to side } \\
\text { only }\end{array}$ & $\begin{array}{l}\text { Rotation one side } \\
\text { only }\end{array}$ \\
\hline $\begin{array}{l}\text { Tingling- } \\
\text { numbness }\end{array}$ & Absent & Occasionally & Up to $1 \mathrm{hr}$ & Up to $2 \mathrm{hr}$ \\
\hline
\end{tabular}




\section{Observation and Result}

For this study, the subjective assessment of Dependent variables was done \& appropriate statistical test was applied to find out the significance of treatment. The Demographic analysis like age sex etc. is not purview in the present study therefore we have not drawn any conclusion from it.

The demographic analysis on this study revealed a number of acceptable facts. The age group of maximum patients with cervical region pain was observed between 41 to 50 . Cervical spondylosis was observed to be dominant in females $(60 \%)$ compared to Males. It was dominant in Vata-Kapha (62\%), Vata-Pitta (38\%). The condition was (64\%) prevalent in housewife and $32 \%$ in shopkeeper patients.

Subjective parameters are taken for the statistical analysis of data in which Wilcoxon Matched pair test was applied.

Out of 50 patients assessing symptomatic relief for 6 parameters viz. Pain, stiffness, flexion, extension, lateral movement and tingling numbness. Agnikarma with modified device (locally)and Ashwagandha Ghanavati (internally) proved efficacious in the management of 'ManyagataVata' with 'p' value less than 0.001 showing highly significant. The statistical observations on dependable variables revealed that among 50 patients $92 \%$ patients got complete relief from cervical pain, $98 \%$ patients got relieved from Stiffness and restricted movements of neck, Tingling numbness present were relieved in $96 \%$ patients(table no. 2 ).

Table 2: Showing the statistical analysis for subjective parameters

\begin{tabular}{|c|c|c|c|c|c|c|c|c|}
\hline Variables & & MEAN & SD & MEDIAN & $\mathbf{N}$ & $\mathbf{W}$ & $\overline{\mathbf{P}}$ & Result \\
\hline \multirow[t]{3}{*}{ Pain } & BT & 8.94 & 0.62 & 9.00 & \multirow[t]{3}{*}{49} & \multirow[t]{3}{*}{1225.0} & \multirow[t]{3}{*}{$<0.001$} & \multirow{3}{*}{$\begin{array}{c}\text { Highly } \\
\text { Significant }\end{array}$} \\
\hline & $\mathrm{AT}$ & 3.58 & 1.76 & 4.00 & & & & \\
\hline & Difference & 5.36 & 1.8 & 5.00 & & & & \\
\hline \multirow[t]{3}{*}{ Stiffness } & $\mathrm{BT}$ & 2.6 & 0.52 & 3.00 & \multirow[t]{3}{*}{49} & \multirow[t]{3}{*}{1225.0} & \multirow[t]{3}{*}{$<0.001$} & \multirow{3}{*}{$\begin{array}{c}\text { Highly } \\
\text { Significant }\end{array}$} \\
\hline & $\overline{\mathrm{AT}}$ & 0.62 & 0.64 & 1.00 & & & & \\
\hline & Difference & 2.04 & 0.81 & 2.00 & & & & \\
\hline \multirow[t]{3}{*}{ Flexion } & BT & 2.8 & 0.4 & 3.00 & \multirow[t]{3}{*}{49} & \multirow[t]{3}{*}{1225.0} & \multirow[t]{3}{*}{$<0.001$} & \multirow{3}{*}{$\begin{array}{c}\text { Highly } \\
\text { Significant }\end{array}$} \\
\hline & $\mathrm{AT}$ & 0.74 & 0.63 & 1.00 & & & & \\
\hline & Difference & 2.06 & 0.74 & 2.00 & & & & \\
\hline \multirow[t]{3}{*}{ Extension } & BT & 2.56 & 0.54 & 3.00 & \multirow[t]{3}{*}{49} & \multirow[t]{3}{*}{1225.0} & \multirow[t]{3}{*}{$<0.001$} & \multirow{3}{*}{$\begin{array}{c}\text { Highly } \\
\text { Significant }\end{array}$} \\
\hline & $\mathrm{AT}$ & 0.64 & 0.61 & 1.00 & & & & \\
\hline & Difference & 1.92 & 0.78 & 2.00 & & & & \\
\hline \multirow{3}{*}{$\begin{array}{c}\text { Lateral } \\
\text { Movement }\end{array}$} & $\mathrm{BT}$ & 2.62 & 0.49 & 3.00 & \multirow[t]{3}{*}{49} & \multirow[t]{3}{*}{1225.0} & \multirow[t]{3}{*}{$<0.001$} & \multirow{3}{*}{$\begin{array}{c}\text { Highly } \\
\text { Significant }\end{array}$} \\
\hline & $\mathrm{AT}$ & 0.70 & 0.54 & 1.00 & & & & \\
\hline & Difference & 1.92 & 0.78 & 2.00 & & & & \\
\hline \multirow{3}{*}{$\begin{array}{c}\text { Tingling } \\
\text { Numbness }\end{array}$} & BT & 2.64 & 0.53 & 3.00 & \multirow{3}{*}{48} & \multirow{3}{*}{1176.0} & \multirow{3}{*}{$<0.001$} & \multirow{3}{*}{$\begin{array}{c}\text { Highly } \\
\text { Significant }\end{array}$} \\
\hline & $\mathrm{AT}$ & 0.52 & 0.61 & 0.0 & & & & \\
\hline & Difference & 2.12 & 0.87 & 2.00 & & & & \\
\hline
\end{tabular}

Table 2: Showing overall effect of therapy result.

\begin{tabular}{|l|l|c|c|c|c|c|}
\hline $\begin{array}{l}\text { Sr } \\
\text { no }\end{array}$ & Effect of therapy & \multicolumn{5}{|c|}{ Parameters } \\
\hline & & Pain & Stiffness & $\begin{array}{c}\text { Flexion } \\
\text { extension }\end{array}$ & $\begin{array}{c}\text { Lateral } \\
\text { movement }\end{array}$ & $\begin{array}{c}\text { Tingling - } \\
\text { numbness }\end{array}$ \\
\hline 1 & Cured & 0 & 0 & 0 & 0 & 0 \\
\hline 2 & Relieved & $92 \%$ & $98 \%$ & $98 \%$ & $98 \%$ & $96 \%$ \\
\hline 3 & $\begin{array}{l}\text { Markedly } \\
\text { Improved }\end{array}$ & $5 \%$ & $2 \%$ & $2 \%$ & $1 \%$ & $3 \%$ \\
\hline 4 & Improved & $3 \%$ & 0 & 0 & $1 \%$ & $1 \%$ \\
\hline
\end{tabular}




\section{Discussion}

Cervical Spondylosis is described as degenerative condition of the cervical spine. It is found most commonly in individuals aged 40-50 years, leads to symptoms like pain, restricted movement stiffness and tingling-numbness at neck region which resembles with ManyagataVata.Inallopath, analgesic, corticosteroid, Muscle relaxants and calcium supplements are prescribed, but with longer time has side effects, soits use is limited. Further, in advancement of disease (CSM and Neurological involvement) surgical intervention like laminectomy, decompression, implants etc. are practiced with due risk (11).

Ayurvedic experts manages this condition with various Panchkarma such as Basti, Raktamokshan, Nasya, Lepa etc. adjuvant to Vata-Kaphashamak and AsthiDhatuvardhanpalliative drugs. Similarly, Agnikarma is also practiced in Manyagatavata which helps in reducing pain instantly. Hence, the proposed study was primarily aimed to evaluate the efficacy of Agnikarma and Ashwagandha ghanavati in Manyagatavata w.s.r. to cervical spondylosis.

Agnikaram is established and practiced since many years. As Ancient conventional method of Agnikarma consist of limitation like variable heat source (flame, spirit lamp), intermittent multiple heating shalaka which is also time consuming, fluctuation in temperature resulting in inadequate and variable heat delivery and also have due risk of iatrogenic burn which leads in bad prognosis as do not give desire result to patients. Hence, the Agnikarma device is modified which consist of temperature controlling unit with specially designed Raupya shalaka resembling trikurchak shastra.

\section{Modified Agnikarm device electrical circuit (12)}

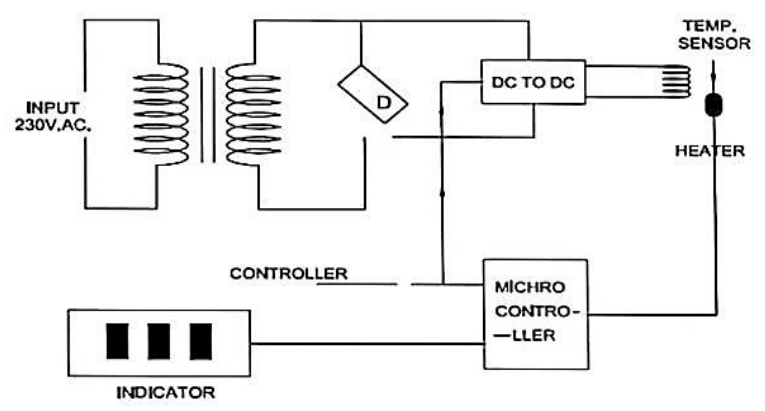

\section{Image 3: Showing circuit diagram for temperature controlling unit}

In this circuit,firstly, AC (Alternating current) current from electric source (standard current of 230 volts) always flows in alternating(periodically) direction which drives to transformer (13). Transformer helps in either increasing or decreasing the voltage as required; it helps in transforming the $\mathrm{AC}$ current (230 volt) through the electromagnetic field (14) and which further moves to Rectifier. The Rectifier rectifies the current by converting $\mathrm{AC}$ current in to $\mathrm{DC}$ (direct current) which flows in one direction (15). After Converting from $\mathrm{AC}$ to $\mathrm{DC}$ it further passes in $\mathrm{DC}$ to DC converter. This DC to DC converter is used to decrease the high voltage current to low voltage current as essential for the circuit (16). Thereafter, this current flows to Temperature sensor also acts like thermocouple which entails the two different electrical conductor forming electric junctions at different temperature, it detect the required amount of temperature and directs the temperature(17) to Heater. As the electric current reaches the heater it is changed to heat energy (18). This Heat energy further drives in Micro controller which is made up of processor and Input/output peripherals on a chip, it controls the input temperature sensed from temperaturesensor and give us the indicator i.e. output(19). In this device handle, specially designed probe is attached to deliver the desired heat to the affected site. This silver probe isTrikurchaktypeofRaupyashalakaconsists of multiple small probes/pins of sliver which produces the grade 2 burn at once, instead of repeated burn. This probe was designed to minimize the pain by applying it on skin for once on tender point.

\section{Probable mode of action}

Agnikarma therapy-Mechanism and action of Agnikarma can be understood with the help of afferent spinothalamic tract. In this the ascending neurons are the pathway for conduction of Pain (lateral spinothalalmic tract- A $\delta \&$ C Fibres), Pressure (ventral spinothalamic tract - Ruffiniendings), Temperature (lateral spino-thalamic tract). When perception of pressure and temperature factor is increased, pain perception is reduced which helps us to understand the role of Agnikarmain relief of pain. Moreover, another hypothesis suggests that the released heat could have caused irritation on the superficial sensory nerve endings thereby relievingpain from the concept of 'counter irritation'. It has also been suggested that pain may be possibly caused as a result of the accumulation of metabolic waste products in the tissues, and an increased flow of blood (vasodilatation due to heat) in the region is the possible mechanism that is responsible to remove these substances and relieve pain. Another possibility is that the pain releasing mechanism is associated with muscle relaxation (20).

Ashwagandha Ghanavati- Ashwagandha possess properties such as Tikta Rasa(bitter taste),Rasayan (rejuvenator) and Balya (nourishing) which helps in controlling degenerative changes of bony tissue and also consist of Cox-2 enzyme which helps in relieving pain and break the pathogenesis. It's also thought to have some anti-inflammatory properties. For this reason, some research has shown it to be effective in treating arthritis (21).

\section{Conclusion}

In this study, the common symptoms of 'Manyagata Vata' like pain, stiffness, restricted neck movements and tingling numbness were relieved with 'Agnikarma (locally done with modified device of Agnikarma) and Ashwagandha ghanavati internally which proved statistically significant.

Out of 50 patients assessing symptomatic relief for 6 parameters like Pain, stiffness, Flexion, extension, lateral movement and tingling numbness for each 
parameter. Among 50 patients $92 \%$ patients got complete relief from cervical pain, $98 \%$ patients got relieved from Stiffness and restricted movements of neck, Tingling numbness present was relieved in $96 \%$ patients. Hence, it can be concluded that Agnikarma therapy with adjuvant Ashwagandha ghanavati proved highly significant in the management of Manyagata Vata.(table no 3)

The modified device for Agnikarma proved user friendly, safe (without iatrogenic effects) and made procedure swift.The interpretation of efficacy and probable mechanism of action of Agnikarma can be explained by combined result i.e. by the action Agnikarma (locally) and Ashwagandhaghanvati (internally).However, it is recommended that the further study should be carried out in large sample size to evaluate and analyze the results. The exact mechanism of action of A gnikarma is to be studied.

\section{References}

1. Ronald Mc Rae: Clinical Orthopedic examination, $6^{\text {th }}$ edition Churchill livingstone, $2010 \mathrm{p} 4$

2. Caraka, Vatvyadhi chikitsaadhyay. In: Vaidyamanorama Hindi Commentary, AcharyaVidyadharShukla, Prof. Ravi DuttTripathi, Caraka Samhita Uttarardha, 2nd ed. Varanasi: Chaukhamba Sanskrit Pratishthan; 2007. p. 699, 28:59.

3. G.D.Singhal: Sushruthasamhitha: With English translation of text edited and translated 2nd edition vol 1. Varanasi: Chowkambha Publishers; 2007.p 158,159

4. Amar Prakash Dwivedi, Lakshmi Subraja Kanikkannan, Shanmugamurthy Lakshmanan, AGNIKARMA: A Reference Manual for Ayurvedic Physicians - Information Directly Extracted from Approximately 3000 Years Old Literature Ayurvedic VRI press vedic research onine USA Ayurvedic, November 2015 Accepted: June 21st, 2015, Volume 2, Issue 2 (eISSN: 2375-6586) p-1-6

5. Narendra Singh, MohitBhalla, Prashanti de Jager and MarilenaGilca, an overview on ashwagandha: a rasayana (rejuvenator) of Ayurveda African journal of traditional complementary and Alternative medicines (AJTCAM) Published online $2011 \mathrm{Jul} 3$.

6. http://physics.iitm.ac.in/ sercehep2013/

Temperature_Controller.pdf Dec 2013
7. Sastry J L N : Dravyaguna Vijnyana Study of the Essential Medicinal Plants in Ayurveda (Illustrated) volume 2 Published by Chaukhambha Orientalia, Varanasi, 2004 p 82

8. Prasad P.V.N.R: Bhaishajya Kalpana vijnyana $1^{\text {st }}$ edition 2008 Choukhamba krishnadas academy choukamba publishers, p. 200,201

9. Amarprakash Dwivedi and Shanmugamurthy Lakshmanan, A Clinical Study of Efficacy of Agnikarm: An Ancient Treatment Method in the Management of Heel Pain Ayurvedic VRI press Vedic research online USA, March 2015 vol 2 Issue 1, p 19,26

10. Vyasdevmahanta-agnikarma-sandhigata vata-shalya -2005 ipgt\&r, jamnagar, gujarat

11. Amarprakash Dwivedi, Role of Panchtiktaghrit nasya, \& internally (oral use) in manyasandhigata vata w.s.r to cervical spondylosis. Ayurvedic Renaissance quarterly scientific journal OctoberDecember 2011 vol IX p 10-12

12. Kalsi H.S: Electronic instrumentation 2nd edition Tata McGraw Hill education private Limited New Delhi, reprint 2009, p-51

13. https://www.electronicshub.org/introduction-toalternating-current-2/ Sep 13, 2016

14. http://www.circuitstoday.com/transformer July 27, 2017

15. https://www.physics-andradioelectronics.com/ electronic-devices-and-circuits/rectifier/rrectifierwhatisrectifier.html October 14, 2014

16. https://www.efxkits.co.uk/dc-dc-converteroperating-principle-functionality/Jan 3, 2015

17. https://wiki.metropolia.fi/display/sensor/ Temperature+SensorsMay 7, 2015

18. https://www.britannica.com/technology/electricheater June 42017

19. https://www.futureelectronics.com/en/ microcntrollers.aspx June 2017

20. DwivediAmarprakash P.,ChaugulePradnya D, Pain management through Ayurveda:A meticulous review. Ayurveda:A meticulous review International Ayurvedic Medical Journal, India Published online: May, 2018.(ISSN: 2320 5091) Volume 2, Issue 4, p-1179,1182

21. https://www.theayurvedaexperience.com/blog/ ashwagandha-for-arthritis/ March 24, 2018 